\title{
INFLUENCE OF QUALITY OF HEALTH SERVICES ON PATIENT SATISFACTION IN ISLAMIC HOSPITAL " $X^{\prime \prime}$ IN 2021
}

\author{
Dwiki Hastomo Putra ${ }^{1}$, Fauzan Firdaus ${ }^{2}$, Muhammad Dzikri Mustofa ${ }^{3}$, Muhammad Uweis Al- \\ Qorny Virdinant ${ }^{4}$ \\ 1,2,3,4 Faculty of Public Health, Muhammadiyah University of Jakarta \\ Email: $\underline{\text { dwikyhastomo@gmail.com }}$
}

\begin{abstract}
Hospital is a health service institution that provides complete individual health services that provide inpatient, outpatient, and emergency services. Indeed, a health service provider can provide maximum service by the expectations and desires of patients. This research is in the form of qualitative and uses a Cross-Sectional study to see the relationship between the quality of services provided to patient satisfaction at Islamic Hospital $X$ in 2021. The data collection procedure was carried out by observation, interviews, and literature studies that took place from May to July 2021. The results showed that based on the dimensions of Reliability, Responsiveness, Assurances, It can be seen from the alertness indicators of health workers, the availability of adequate and modern medical devices, communication skills of health workers, the appearance of health workers, in general, showing good results and leading to patient satisfaction with the services received at Islamic Hospital X in 2021.
\end{abstract}

Keywords: Health Service, Satisfaction, Quality 


\section{INTRODUCTION}

Hospital is a health service institution that provides complete individual health services that provide inpatient, outpatient, and emergency services. (Permenkes RI, 2016). Service quality is an effort to fulfill the needs and desires of consumers and how far the difference between reality and the expectations of customers for the services they get. If the facts or data are further than expected then it can be said to be very good, whereas if the facts or data are less than expected then the service can be said to be not good. If the facts or data are the same between what is expected and reality, the service is called good (Zeithaml et al in Tores, 2015).

According to Kotler (2005), consumer satisfaction is the extent to which a product level is perceived by buyer expectations. This means a situation where consumer expectations of products or services are by the reality received by consumers If the product is far below expectations, consumers will be disappointed. Conversely, if the product meets expectations, consumers will be satisfied. Consumers' expectations can be known from their own experiences when using the product, information from other people, and promotions obtained from advertisements or other promotions.

Research conducted by (Pusporini, 2014) towards patients at Prikasih Hospital shows that the dimensions of reliability, responsiveness, assurance, empathy, and tangibles together affect the satisfaction of patients who visit Prikasih Hospital.

According to the results of research from Ekateria et al, there are still problems with access to outpatient services $5.41 \%$ and infrastructure by $5.71 \%$ of patients feeling dissatisfied, and the lowest percentage of dissatisfaction felt at the time of wait as desired for the visit and the scheduled date $14.71 \%$ of patients are very dissatisfied with the waiting time for services.

This study aims to examine the relationship between service quality in terms of reliability, responsiveness, assurances, empathy, and tangibles to patient satisfaction. In this study, it is expected that there will be an influence of service quality on patient satisfaction at Islamic Hospital X in 2021.

\section{METHODS}

This research is qualitative research using a cross-sectional study design. This study aims to find out how and why a health event occurs. Cross-sectional is research that studies the relationship between risk factors (independent) and effect factors (dependent), which conduct interviews or measure variables once and at the same time. (Riyanto, 2011 in Azizah, 2016). 
This research will be carried out from May to July 2021, which is located at Islamic Hospital X. The data collection procedure used in this study interviews, where the authors ask several questions to visitors who do the treatment at Islamic Hospital X.

\section{RESULTS AND DISCUSSIONS}

In a service company, service is the key to the level of success. Service quality is the level at which the services provided can match customer satisfaction or the level at which service personnel truly understand what is expected by customers and can understand customer satisfaction and desires.

The types of services provided by Islamic Hospital $X$ are inpatient and outpatient. In general, services at Islamic Hospital X have achieved several patient satisfaction criteria, including:

The results showed that the alertness of the health workers was highly expected by all patients who visited Islamic Hospital $\mathrm{X}$. The responsiveness greatly affected patient satisfaction so that patients felt happy with the services provided.

The results of research conducted by (Kusuma Persada, et al 2019) show that the quality of service on the responsiveness dimension at the Pendang Health Center, Dusun Utara District, has the highest number of respondents responding very well. This is because Puskesmas officers can show readiness in responding to requests, questions, and complaints from patients and show a willingness to help patients

The results of the study indicate that the services provided by health workers at hospital agencies create trust in services and medical personnel who are reliable in handling patients so that they can motivate patients to recover quickly.

According to Zeithaml et al 1990 (in Hardiayansyah, 2001: 42) an assessment that affects the quality of service on the dimension of assurance, or guarantee, is to foster customer trust in service providers on the components of communication (communication), credibility (credibility), security (security), competence (competence), and courtesy (courtesy). In this study, it is known that to assess the trust can be seen through the assessment of indicators on timeliness that has been appropriate and appropriate, cost guarantees, guarantees of legality, courtesy.

The results of the study indicate that adequate and modern medical equipment can facilitate health services for patients so that patients can be handled quickly and well. And health workers who look neat can be considered good in handling and vice versa if health workers do not look neat can cause a bad impression in handling.

According to Nimran 1996 (in Sopiah, 2008: 5), The tangible dimension is closely related to organizational behavior from the organizational level. The level of organizational behavior analysis at the 
organizational level assesses organizational behavior is not the sum of individual behavior or group behavior with groups. As well as the tangible dimension (physical evidence) which of course is strongly influenced by the structure, norms, culture, strategy, vision, mission and policies of the organization. In this study, it was found that the indicators measured in the tangible dimension, namely the assessment of the appearance of employees in this study were included in the good category, this was indicated by the appearance of service employees at the PONED Health Center who had a neat appearance and wore clothes by the stipulated provisions. Furthermore, in the use of technology, the results obtained are good, this is related to the use of computers in the administrative process, and other medical devices that have taken advantage of technological advances. Nurses who pay attention to appearance when interacting with clients both in terms of the use of uniforms, neatness, and cleanliness, as well as the actions of nurses will create a nurse's self-image and professionalism in the eyes of clients which can affect the quality and quality of nursing services both in hospitals and health centers. As stated by Arwani (2003) Neatness and cleanliness, as well as the actions of nurses will create a nurse's self-image and professionalism in the eyes of clients which can affect the quality and quality of nursing services both in hospitals and health centers. As stated by Arwani (2003) neatness and cleanliness, as well as the actions of nurses will create a nurse's self-image and professionalism in the eyes of clients which can affect the quality and quality of nursing services both in hospitals and health centers. As stated by Arwani (2003)

The results showed that the communication skills of health workers can lead to patient confidence in health services so that when patients suffer from illness and need help, they can come back to the hospital because they believe in good service.

This is by the results of research on the empathy dimension, especially on indicators of the level of friendliness and patience which are included in the good category and in understanding customers in this study it can be assessed through the assessment of patient appreciation which has been included in the good category and in performing services the officers do not discriminate against patients This is evidenced by the fact that there are no patients who are devoted to getting services. Service users will get services if they have done things according to established service procedures.

The results showed that when the service provided by the health worker was good, the patient was satisfied with the service, and vice versa if the service provided by the health worker was bad, the patient was dissatisfied with the service. As well as handlers who are ready to be fast and responsive add to the patient's confidence.

Winardi (2004:201) reveals that abilities and skills are individual variables in behavioral theory. Ability is a trait (inherent in humans or learned) that allows a person to carry out some mental or physical 
action or work. Skills are competencies related to tasks such as computer operating skills, or communication skills clearly for group goals and missions. In this study it was found that the skills and abilities of service officers were in a good category, this can be seen through the assessment indicators of good examination accuracy, Accuracy in administering good drugs due to the presence of special officers giving drugs, clarity of good service standards, service schedules are good and appropriate.

\section{CONCLUSION}

Based on the results of the study showed that Islamic Hospital X provides satisfactory services to patients who do treatment there. It can be seen from the alertness indicators of health workers, the availability of adequate and modern medical devices, communication skills of health workers, the appearance of health workers, in general, showing good results and leading to patient satisfaction with the services received at Islamic Hospital X in 2021.

\section{REFERENCES}

Adisasmito (2008) Health system. Jakarta: Raja Grafindo Persada.

Annisa, N. (2017) 'The Relationship of Service Quality to Satisfaction of Class III Inpatients in Kindergarten Hospitals. Iv Madiun in 2017', Stikes Bhakti Husada Mulia Madiun.

Azizah, MH (2016) 'FACTORS RELATED TO SAFETY RIDING BEHAVIOR IN STUDENTS (Study on Faculty of Mathematics and Natural Sciences UNNES Students Class of 2008-2015)'.

Dewi, M. (2016) 'The Influence of Service Quality on Patient Satisfaction with BPJS Users at the East Aceh District Medical Rehabilitation Hospital', Journal of Management and Finance Unsam, 5(2), pp. 535-544.

Djeinne Thresye Pangerapan, Ora Et Labora I. Palandeng, AJMR (2018) 'RELATIONSHIP BETWEEN QUALITY OF SERVICE AND PATIENT SATISFACTION IN DISEASE POLYCLINIC IN GENERAL HOSPITAL GMIM PANCARAN KASIH MANADO'.

Djoko Wijono (1999) Quality Management of Health Services. Vol 1. Airlangga University Press.

Harun, H. (2020) 'Analysis of Factors Affecting the Quality of Health Services on Patient Satisfaction at the Inpatient Health Center of Pasaman Regency 2019', Human Care Journal, 4(3), p. 138. doi:10.32883/hcj.v4i3.500.

Inap, R. et al. (2015) 'Indra Jaya and Indra Syarufudin E-ISSN 2502-5678', 1(1), pp. 37-41.

Irawan, H. (2004) Customer Satisfaction Principle: The new paradigm captures the hearts of customers to win the competition. Jakarta: PT. grammar.

Jihan Natassa, A. (2017) 'RELATIONSHIP OF QUALITY OF SERVICE WITH PATIENT 
SATISFACTION IN THE INPATIENT ROOM OF PEKANBARU ARMY HOSPITAL', 7(2), pp. 93-98.

Ministry of Health RI (2010) 'Hospital Classification', p. 116.

Ministry of Health (2009) Regulation of the Minister of Health Number 36.

Ministry of Health (2016) Regulation of the Minister of Health Number 34. Indonesia.

Lupiyoadi, R and Hamdani, A. (2009) Service Marketing Management. Jakarta: Four Salemba.

Nuviana, W., Noor, M., and Jauchar (2018) 'The Influence of Health Service Quality on Patient Satisfaction with BPJS users at UPTD Puskesmas Lempake', Journal of Government Science, 6(4), pp. 1621-1634.

Pohan, Imbalo S (2007) Health Service Quality Assurance: The basics of understanding and application. Jakarta: EGC.

Pratiwi, AD et al. (2019) 'Relationship between Quality of Health Services and Satisfaction of National Health Insurance Participant in the District Hospital of North Buton in 2018', Medula, 6(3), pp. 606-615. doi:10.46496/medula.v6i3.9645.

Pratiwi, S., and Susanto (2016) 'The Effect of Service Quality on Satisfaction of Inpatients at Sultan Immanudin Hospital Pangkalan Bun, Central Kalimantan', Journal of the Association of Muhammadiyah Lecturers Masters in Hospital Administration, 2(2), pp. 1-9.

Pusporini, HR (2014) 'Analysis of the Effect of Service Quality on Patient Satisfaction Levels at Prikasih Hospital', Proceedings of the National Seminar \& Call For Papers (SCA-4), 4(1), pp. 299-311. Available at: http://jp.feb.unsoed.ac.id/index.php/sca-1/article/view/685.

Satrianegara, M. Faris and Saleha, S. (2009) Textbook of Organization and Management of Health and Midwifery Services. Jakarta: Salemba Media.

Tanti, M. (2017) 'RELATIONSHIP OF THE QUALITY OF HEALTH SERVICES TO THE LEVEL OF INCIDENTAL PATIENT SATISFACTION IN HASANAH GRAHA AFIAH GENERAL HOSPITAL IN 2017'.

Tores, R. (2015) 'The Effect of Service Quality on Outpatient Satisfaction at Public Health Centers in Musi Banyuasin Regency', Journal of Management Science, 5(1), p. 287555. doi:10.32502/jimn.v5i1.308.

Utami, AT, Ismanto, H. and Lestari, Y. (2013) 'The Influence of Service Quality on Patient Satisfaction (Case Study of Outpatients in the Emergency Unit of Bhayangkara Hospital Education Center Mobile Brigade Watukosek)', Jkmp (Issn. 2338- 445X, 1(1), pp. 83-96. doi:10.1017/CBO9781107415324.004. 